\title{
PENGGUNAAN DIGITAL BOOK BERBASIS ANDROID UNTUK MENINGKATKAN MOTIVASI DAN KETERAMPILAN MEMBACA PADA PELAJARAN BAHASA ARAB
}

\author{
Mumu Muhammad, Dian Rahadian, Erna Retna Safitri \\ SMA Bidayatul Faizin, STKIP Garut, STKIP Garut dan UNJ Jakarta \\ amoem99@gmail.com, dianrahadian@yahoo.com, erna.retnasafitri@gmail.com
}

\begin{abstract}
Media utilization technology as supporting learning activities more open. Good learning can be supported from a conducive learning environment as well as the communication link between teachers, students can run well. The learning process will be effective when utilizing the various facilities and infrastructure provided includes utilizing a variety of media study. Ironic when the rapid technological developments, the tendency of the learning process that occurs at this time are mostly conventional learning monotonous so it is not able to explore the potential of students and only pose a stiff learning makes students feel bored during the course of the learning process. To solve the above problems, the teacher should be able to create a state of active learning, creative, effective and fun. The integration of the learning process of students with the teacher's teaching has led to an instructional activities that harmony does not come alone but through the settings using the media as one of support in learning activities, one of the efforts undertaken in this study is the use of media android as a learning medium to increase motivation and reading skills of students in learning Arabic. This study uses a quasiexperimental method with de esain study is a non-equivalent control group pre-test and posttest design, using two-class as an experimental class and control class. Begins by providing an early test to identify students' mastery of skills. Then implemented learning by using media digital books in the experimental class and ordinary classroom learning control. After learning is completed the final test to identify students 'motivation, improved reading skills and to measure students' reading skills. Then the data obtained were analyzed with statistical analysis. The results showed that the use of digital media android based eBook positive effect on student motivation and positive influence on the improvement of students' reading skills in learning Arabic sub subject Bidayatul Faizin I'rob in high school.
\end{abstract}

Keywords: Digital Book, Android, Motivation, Reading Skills Arabic

\section{A. PENDAHULUAN}

Seiring dengan perkembangan teknologi informasi dan komunikasi, dewasa ini perangkat teknologi sudah menyebar luas tanpa memandang status baik ekonomi, sosial, pendidikan, dan sebagainya. Salah satunya adalah telepon genggam atau telepon selular. Terutama di kalangan remaja atau masa usia sekolah. Telepon selular mengalami kemajuan yang sangat pesat. Daya kompetitif untuk menembus pangsa pasar yang sangat luas semakin ketat.

Senada dengan kajian teknologi pembelajaran, penetrasi pemanfaatan media teknologi sebagai penunjang kegiatan pembelajaran semakin terbuka. Pembelajaran yang baik dapat ditunjang dari suasana pembelajaran yang kondusif serta hubungan komunikasi antara guru, siswa dapat berjalan dengan baik. Proses pembelajaran akan efektif ketika memanfaatkan berbagai sarana dan prasarana yang tersedia termasuk memanfaatkan berbagai media belajar.

Saat ini, fasilitas telepon selular tidak hanya sebagai sarana berkomunikasi saja, tetapi banyak fitur-fitur lain atau tambahan yang ditawarkan oleh produsen terutama produsen software untuk menunjang aktifitas manusia 
dalam menjalani kehidupan seharihari. Telepon selular sudah menjadi aksesoris setiap orang, khususnya remaja termasuk siswa. Namun kebanyakan penggunaan telepon selular di kalangan siswa baru sebatas alat komunikasi.

Masalah mendasar lain dialami dalam kegiatan pembelajaran bahasa Arab adalah kurangnya antusiasme siswa selama dalam proses pembelajaran sehingga hasilnya pun akan otomatis tidak optimal, apalagi kalau dikaitkan dengan standar ketuntasan belajar dan pemerintah dimana setiap siswa harus sudah mencapai minimal 75\% (Buku Saku KTSP 2006 Dirjen Dikdasmen). Namun berdasarkan pengamatan yang dilakukan terhadap siswa SMA Bidayatul Faizin Cikajang, sering terjadi kesenjangan antara tujuan yang ingin dicapai dengan kenyataan yang dihadapi. Selain itu, keterampilan berbahasa Arab terutama keterampilan membaca masih sangat rendah. Fenomena ini dapat dilihat dari hasil tes formatif maupun sumatif, nilai mata pelajaran bahasa Arab sering tidak mencapai nilai KKM, yaitu 75 untuk nilai KKM bahasa Arab yang ditetapkan di SMA Bidayatul Faizin tersebut. Itu semua karena pembelajaran yang cenderung monoton membuat siwa tidak maksimal dalam belajar.

Di samping itu juga, banyak faktor yang menyebabkan hal itu terjadi, selain faktor dari siswa itu sendiri, guru juga menjadi faktor yang cukup signifikan dalam menentukan keberhasilan siswa dalam belajar. Di samping itu juga, masalah yang cukup urgen adalah ketersediaan media belajar di sekolah. Buku pelajaran bahasa Arab masih terbatas jumlahnya, sedangkan telepon seluler hampir semua siswa memiliki.

Mengingat fungsi dan fitur telepon selular terutama smartphone atau yang berbasis android bukan hanya sebagai media komunikasi saja, akan tetapi banyak fitur lain seperti, office, video, ebook, digital book reader, dan sebagainya. Untuk itu, penulis tertarik untuk melakukan penelitian yang berkaitan dengan problematika tersebut. Penelitian ini bertujuan untuk mengetahui:
1. Efektifitas penggunaan media digital book berbasis android dalam meningkatkan motivasi belajar; dan

2. Efektifitas penggunaan media digital book berbasis android dalam meningkatkan keterampilan membaca.

\section{B. KAJIAN LITERATUR}

\section{Konsep Pembelajaran}

Pembelajaran merupakan proses manusia dalam memenuhi segala kebutuhan hidupnya. Kata pembelajaran merupakan terjemahan dari learning yang berasal dari kata to learn. Menurut Surya (2013:111) pembelajaran menggambarkan suatu proses yang dinamis karena pada hakikatnya perilaku belajar diwujudkan dalam suatu proses yang dinamis dan bukan pada sesuatu yang diam atau pasif. Sedangkan menurut Brown (2007:8) pembelajaran adalah penguasaan atau pemerolehan pengetahuan tentang suatu subyek atau sebuah keterampilan dengan belajar, pengalaman atau instruksi. Jadi pembelajaran merupakan upaya yang dilakukan oleh seorang guru atau yang lain untuk membelajarkan siswa yang belajar.

a. AECT (Association for Education and Communication Technology) mendefinisikan media, yaitu segala bentuk yang dipergunakan untuk suatu proses penyaluran informasi (dalam Sadiman dkk, 2010).

b. NEA (Educations Association) mendefenisikan sebagai benda yang dapat dimanipulasi, dilihat, didengar, dibaca atau dibicarakan beserta instrumen yang dipergunakan dengan baik dalam kegiatan belajar mengajar dapat mempengaruhi efektifitas program instruktional (Sadiman dkk, 2010). 
Dari defenisi-defenisi tersebut dapat ditarik kesimpulannya bahwa pengertian mediamerupakan sesuatu yang bersifat menyalurkan pesan dan dapat merangsang pikiran, perasaan dan kemauan audio (siswa) sehingga dapat mendorong terjadinya proses belajar pada dirinya.

\section{Guru dan Media Pembelajaran}

Menurut Munadi (2008) Sistem pendidikan yang baru menuntut faktor dan kondisi yang baru pula baik yang berkenaan dengan sarana fisik maupun nonfisik. Untuk itu diperlukan tenaga pengajar yang memiliki kemampuan dan kecakapan yang lebih memadai, diperlukan kinerja dan sikap yang baru, peralatan yang lebih lengkap dan administrasi yang lebih teratur.

Guru hendaknya dapat menggunakan peralatan yang lebih ekonomis, efisien dan mampu dimiliki oleh sekolah serta tidak menolak digunakannya peralatan teknologi moderen yang relevan dengan tuntutan masyarakat dan perkembangan zaman. Permasalahan pokok dan cukup mendasar adalah sejauh manakah kesiapan guru-guru dalam menguasai penggunaan media pendidikan dan pengajaran di sekolah untuk pembelajaran siswa secara optimal sesuai dengan tujuan pendidikan dan pengajaran (Munadi, 2008).

\section{Prinsip Pemanfaatan media Pembelajaran}

Menurut Sadiman (2010) prinsip pokok yang harus diperhatikan dalam penggunaan media pada setiap kegiatan belajar mengajar adalah bahwa media digunakan dan diarahkan untuk mempermudah siswa belajar dalam upaya memahami materi pelajaran. Dengan demikian penggunaan media harus dipandang dari sudut kebutuhan siswa. Hal ini perlu ditekankan sebab sering media dipersiapkan hanya dilihat dari sudut kebutuhan siswa.

\section{Digital Book dan Sistem Android}

Pada dasarnya, digital book atau e-book adalah versi elektronik dari teks yang dapat dibaca pada layar desktop atau laptop, PDA atau perangkat portabel lainnya, atau pada perangkat keras pembaca $e$-book. $E$ book dapat menggunakan berbagai format file dan dapat menggabungkan fitur lain, seperti annotations, audio dan video, dan hyperlink. Selain itu, e-book juga dapat mencakup komentar dan alat berkomunikasi (chatting) yang memungkinkan interaksi antar pembaca, dan mengizinkan pembaca menambahkan link ke sumber dari luar. Beberapa produk e-book terikat dengan software untuk membacanya, dan ada juga yang menyediakan $e$ book dalam format, seperti HTML (Educause Learning Initiative, 2005; Lee, 2004 dalam Darmawan, 2013).

Selanjutnya, pengertian digital book menurut Abbott and Kelly (dalam Buzzetto, 2007:240) menerangkan bahwa:

"E-book can be as simple as a scanned version of a printed publication, inherent in e-books is the ability to make available a number of features to the reader which include multimedia, hyperlinks and other interactive components, search features, and customizability to changetext size or convert text to audio so as to meet the needs of special readers."

E-book menawarkan beberapa manfaat bagi pembaca, antara lain dengan memanfaatkan fitur audio, video, dan simulasi yang akan memfasilitasi pemahaman materi pelajaran yang lebih dalam. Selain itu, memberikan kesempatan kepada siswa untuk meningkatkan pemahaman materi pelajaran daripada hanya membaca teks saja. Selain itu, fungsi dari e-book dapat 
diterapkan untuk mengekspresikan makna dari berbagai alat-alat dan pembaca dapat mengalami dan berinteraksi dengan konten dari e-book tersebut. E-book mendorong pembaca untuk aktif dan mandiri dalam cara mereka belajar, dan membebaskan mereka membuat keputusan yang mereka ambil melalui teks (Educause Learning Initiative, 2005).

Selanjutnya, Android adalah Operating Sistem (OS) atau sistem operasi yang sangat populer akhir-akhir. Tidak dapat dipungkiri sistem operasi ini telah banyak mengambil perhatian masyarakat dunia dan masyarakat Indonesia tentunya. Perusahaan gadget dan telepon seluler berlomba-lomba membuat perangkat dengan memakai sistem operasi Android. Oleh karena itu, hampir setiap hari kita melihat gadgetgadget baru beredar di pasaran yang menggunakan sistem operasi besutan google tersebut (Utomo, 2010).

\section{Motivasi Belajar}

Motivasi berasal dari kata motif yang berarti dorongan atau alasan. Motif merupakan tenaga pendorong yang mendorong manusia untuk bertindak atau suatu tenaga di dalam diri manusia, yang menyebabkan manusia bertindak atau melakukan sesuatu. Motivasi merupakan tenaga pendorong yang mendorong manusia untuk bertindak atau melakukan sesuatu. Sedangkan motivasi belajar adalah keseluruhan daya penggerak psikis di dalam diri seseorang yang menimbulkan kegiatan belajar, menjamin kelangsungan kegiatan belajar dan memberikan arah pada kegiatan belajar itu demi mencapai suatu tujuan (Sardiman, 2010).

Pengaruh motivasi terhadap seseorang tergantung seberapa besar motivasi itu mampu membangkitkan motivasi seseorang untuk bertingkat laku. Dengan motivasi yang besar, maka seseorang akan melakukan sesuatu pekerjaan dengan lebih memusatkan pada tujuan dan akan lebih intensif pada proses pengerjaannya. Dalam kegiatan belajar, motivasi dapat dikatakan sebagai keseluruhan daya penggerak di dalam diri seseorang yang menimbulkan kegiatan belajar, yang menjamin kelangsungan dari kegaitan belajar dan memberikan arah pada kegiatna belajar, sehingga tujuan yang dikehendaki oleh subyek belajar itu dapat tercapai (Sardiman, 2010).

Dalam kajian teori motivasi ada yang dikenal dengan teori kebutuhan. Teori ini dikemukakan oleh A.H. Maslow yang mengemukakan bahwa orang termotivasi untuk melakukan sesuatu karena didasari adanya kebutuhan dalam dirinya, yang terbagi menjadi 5 (lima) kebutuhan yaitu: (a) kebutuhan fisiologis yang merupakan kebutuhan manusia untuk bertahan hidup atau juga disebut kebutuhan pokok yang terdiri dari kebutuhan makan, minum, pakaian, dan tempat tinggal; (b) kebutuhan rasa aman yang meliputi keamanan akan perlindungan dari bahaya kecelakaan kerja dan jaminan hari tua; (c) kebutuhan sosial yang berupa kebutuhan-kebutuhan seseorang untuk diterima dalam kelompok tertentu yang menyenangkan bagi dirinya; (d) kebutuhan penghargaan seperti halnya kabutuhan bagi seorang pegawai yang bekerja dengan baik tentu ingin mendapat penghargaan dan pengakuan dari atasan ataupun pujian dari teman kerjanya atas prestasinya dan; (e) kebutuhan aktualisasi diri yang berupa kebutuhan yang muncul dari seseorang dalam proses pengembangan potensi dan kemampuannya untuk menunjukkan jati dirinya yang sebenarnya (Hasibuan, 2003:104-107). 
6. Keterampilan Membaca Bahasa Arab

Membaca menurut Surya (2015:182) merupakan wujud aktifitas kognitif melalui rangsangan (stimulus) yang berupa huruf dan tanda-tanda baca lainya yang diterima oleh indera reseptor visual (mata) untuk kemudian dilanjutkan ke otak dan selanjutnya diberikan tafsiran atau makna. Membaca termasuk keterampilan pokok dalam pembelajaran bahasa disamping keterampilan yang lain seperti mendengarkan, berbicara dan menulis. Dalam pembahasan ini penulis mengemukakan beberapa teknik pembelajaran membaca untuk pemula, tujuan pembelajaran membaca, ragam membaca, dan tema-tema lain yang berkaitan dengan pembelajaran membaca (Hermawan, 2011:116).

Membaca merupakan proses untuk mendapatkan informasi atau pengetahuan. Dalam prakteknya ada beberapa model di dalam membaca, diantaranya (Rosyidi, 2009):

a. Model Membaca Pemahaman b. Model Konstruksi Integrasi
c. Model Konstruksionis

\section{Pembelajaran Bahasa Arab}

Surya (2015:184) memberikan pengertian bahwa bahasa merupakan satu sistem yang kompleks dan luas berupa kesepakatan mengaitkan simbol dengan makna untuk keperluan komunikasi. Titik awal dalam membahas masalah bahasa yaitu makna dan pesan yang biasa digunakan oleh manusia dalam berkomunikasi. Fitur utama dalam bahasa oleh para ahli linguistik disebut pragmatik. Penggunaan bahasa merupakan hal yang paling menarik dalam pembahasan evolusi dan perilaku manusia. Aspek bahasa lainnya adalah struktur bahasa, yang menggambarkan tiga tingkatan struktural yaitu kata-kata, sintaks, wacana. Secara skematis dapat dilihat dalam bagan berikut.

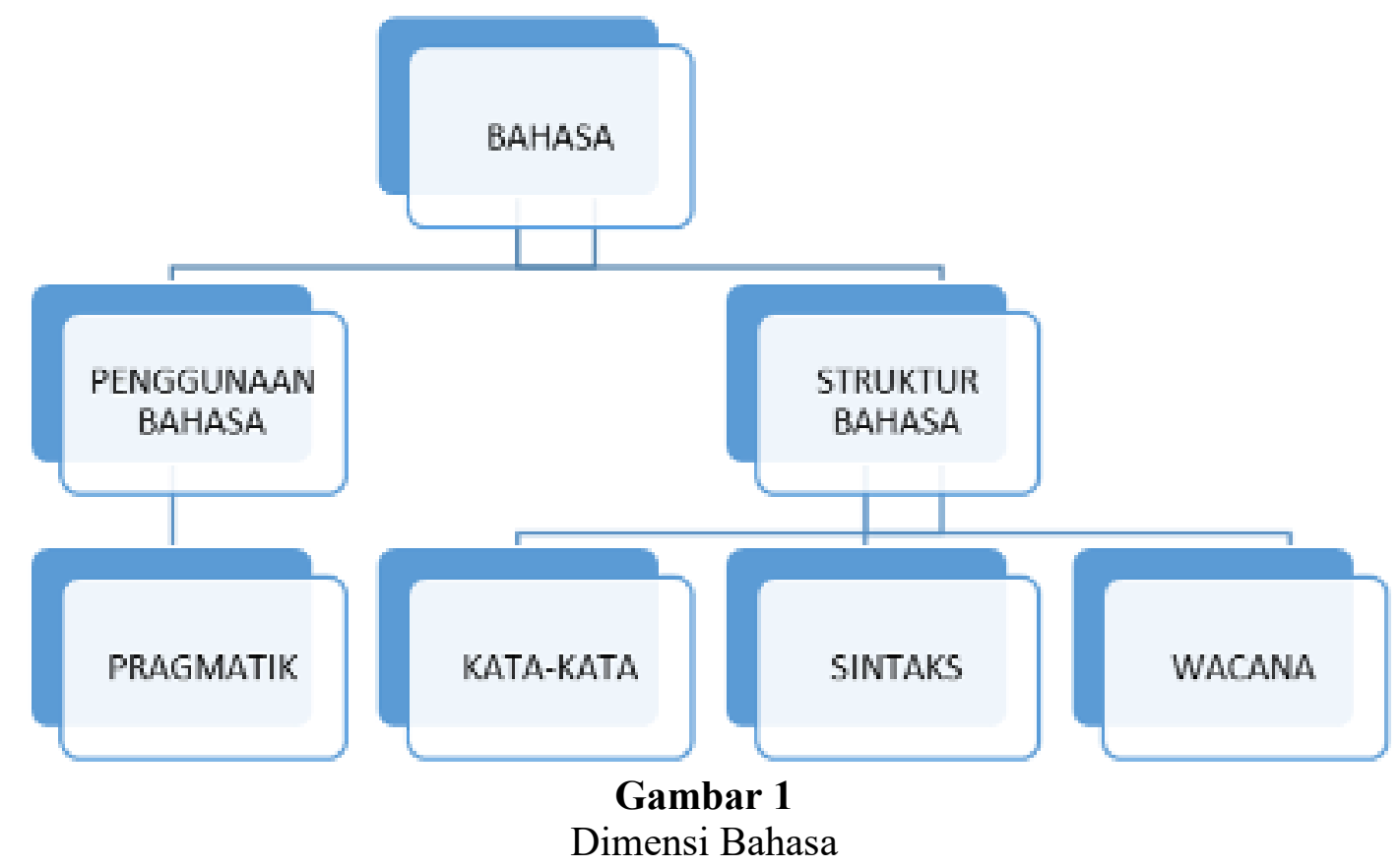

\section{METODOLOGI PENELITIAN}

Desain penelitian yang digunakan adalah Non-equivalent control group pre-test and post-test design, yaitu penelitian yang dilaksanakan pada dua kelas, yaitu satu kelas eksperimen dan satu kelas kontrol, diawali dengan memberikan tes awal untuk mengidentifikasi penguasaan keterampilan awal siswa. Kemudian 
dilaksanakan pembelajaran dengan menggunakan media buku digital. Setelah pembelajaran selesai dilakukan tes akhir untuk mengidentifikasi motivasi belajar siswa, peningkatan keterampilan membaca dan mengukur keterampilan membaca siswa (Arikunto, 2006).

Desain penelitian yang digunakan pada penelitian ini disajikan pada tabel di bawah ini.

\begin{tabular}{|c|c|c|c|}
\hline 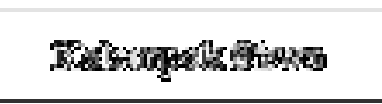 & 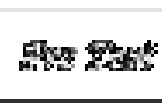 & 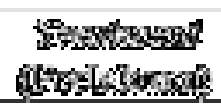 & 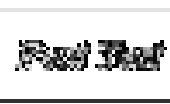 \\
\hline 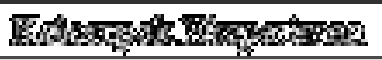 & 6 & $\bar{F}_{\mathrm{i}}$ & $\sqrt{2}$ \\
\hline 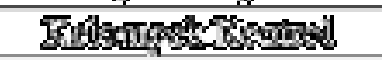 & 5 & 垔被 & 8 \\
\hline
\end{tabular}

\section{Farasonges}

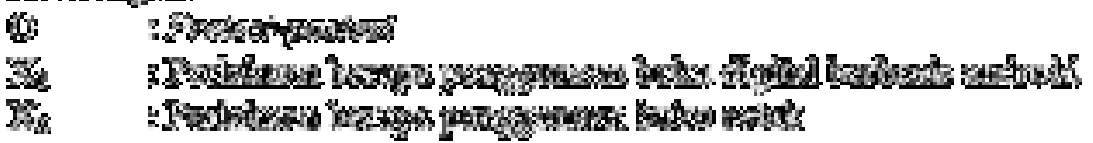

Gambar 2

Desain Penelitian

Berdasarkan uraian di atas, terdapat tiga variabel yang terdiri dari variabel independen (bebas) yang kemudian diberi simbol $\mathrm{X}$ dan variabel dependen (terikat) yang selanjutnya diberi simbol $\mathrm{Y}$, sehingga dengan jelas dapat ditulis sebagai berikut. Variabel $\mathrm{X}$ : Penggunaan digital book berbasis android Variabel Y1 : Motivasi belajar Variabel Y2 : Keterampilan membaca.

\section{Populasi dan Sampel}

Pada penelitian ini, yang dijadikan populasi seluruh siswa kelas $\mathrm{X}$ SMA Bidayatul Faizin yang berjumlah 64 siswa.

\section{Instrumen Penelitian}

Sebagai alat pengumpul data instrumen yang digunakan dalam penelitian ini adalah tes serta angket. Tes merupakan serangkaian soal yang diberikan kepada siswa berupa soal pretest dan soal posttest. Soal pretest diberikan pada siswa sebelum pembelajaran Bahasa Arab, soal ini bertujuan untuk mendapatkan data awal keterampilan membaca siswa pada pembelajaran Bahasa Arab, sedangkan posttest merupakan soal yang diberikan setelah proses pembelajaran Bahasa Arab, soal ini bertujuan untuk mendapatkan data peningkatan keterampilan belajar siswa setelah mendapatkan perlakuan. Banyaknya soal terdiri 5 soal bentuk esay untuk menilai keterampilan membaca yang dinilai oleh penilai (guru) dan 10 soal bentuk pilihan ganda untuk menilai keterampilan pemahaman yang diisi oleh siswa.

Angket motivasi siswa yang dikembangkan dalam penelitian ini berupa skala likert yang dimodifikasi, yakni menggunakan empat kategori respon; sangat setuju (SS), setuju (S), tidak setuju (TS), dan sangat tidak setuju (STS). Instrumen angket digunakan untuk menjaring data motivasi belajar siswa sebelum dan setelah mendapatkan pembelajaran dengan menggunakan media digital book.

\section{Teknik Pengolahan Data}

Dalam melakukan pengolahan data supaya dapat ditarik kesimpulan, dilakukan teknik analisis data dengan langkahlangkah sebagai berikut:

a. Memeriksa angket serta soal yang telah diberi jawaban oleh siswa pada soal pretest maupun soal posttest. 
b. Memberikan skor untuk masingmasing soal serta memberikan nilai.

c. Menyajikan hasil tes tersebut ke dalam bentuk tabel (menggunakan program Microsoft office excel).

d. Menyajikan nilai hasil tes ke dalam bentuk grafik untuk mengetahui peningkatan hasil keterampilan membaca sebelum dan setelah mendapatkan perlakuan (dengan menggunakan bantuan program Microsoft office excel).

e. Menyajikan data hasil penjaringan melalui angket dalam bentuk data deskriptif.
Gain ternormalisasi $(g)$ menurut Meltzer dalam Sundayana (1015: 151) Rumus:

$$
\mathrm{N}-\text { Gain }=\frac{\text { Skor akhir }- \text { Skor }_{\text {awal }}}{\text { Sknr:s..., }- \text { Sknr....., }}
$$

\section{Lokasi dan Waktu Penelitian}

Penelitian ini dilaksanakan di SMA Bidayatul Faizin Kecamatan Cikajang Kabupaten Garut pada bulan Oktober 2015 sampai dengan selesai.

\section{Alur Penelitian}

Penelitian ini dilaksanakan di SMA Bidayatul Faizin. Secara garis besar tahaptahap penelitian ini ditunjukkan pada gambar 2 berikut.

\section{Uji Peningkatan (Gain)}

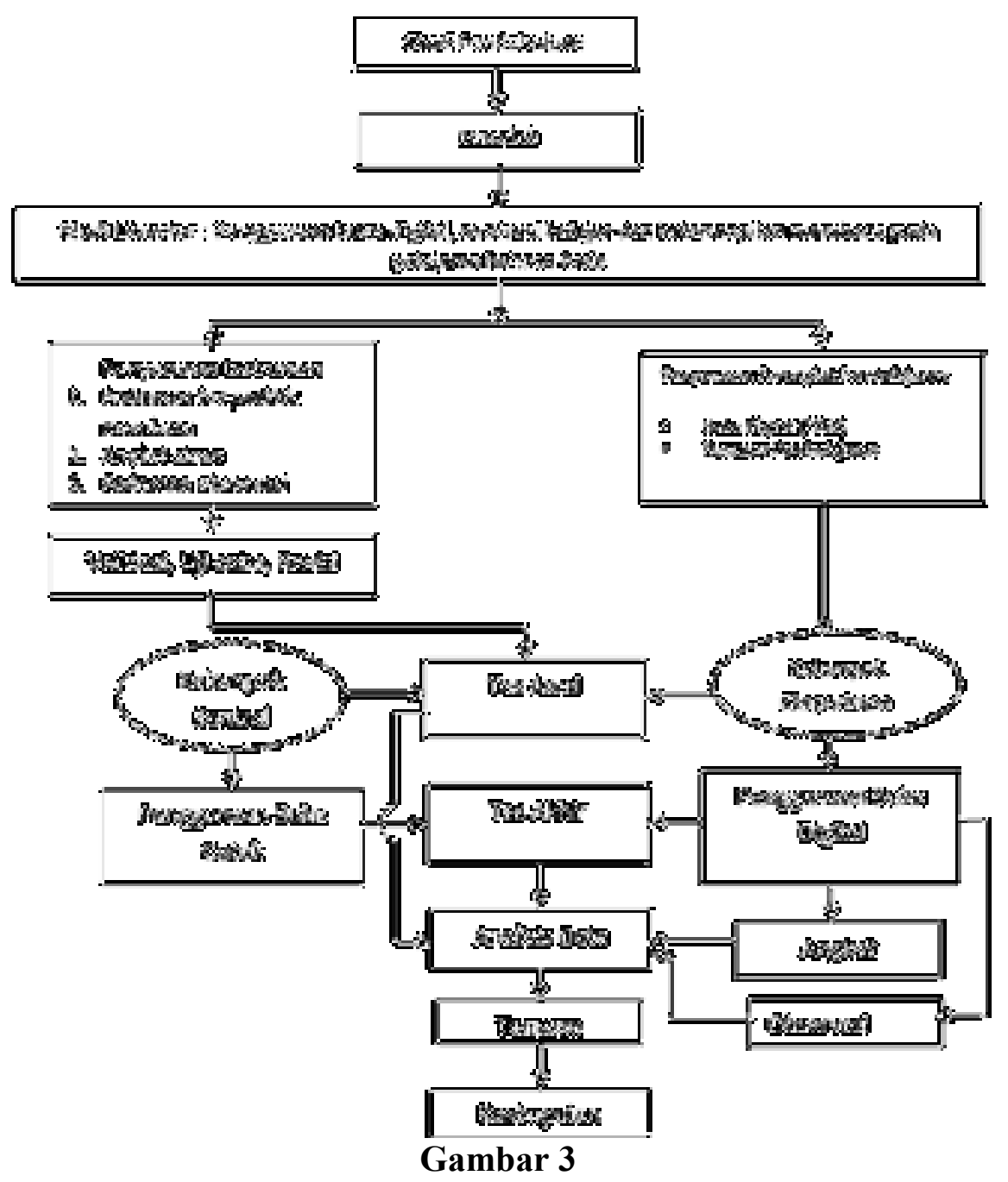

Alur Pelaksanaan Penelitian 


\section{HASIL PENELITIAN DAN PEMBAHASAN}

\section{Hasil Penelitian}

Dari hasil pengujian, untuk menunjukkan apakah ada perbedaan peningkatan hasil belajar, dari kedua rata-rata tersebut dijelaskan dari hasil pengujian yang mana diperoleh nilai Sig.(2-tailed $)=0,000$ sedangkan nilai $\square$ yang digunakan sebesar 0,05 sehingga nilai Sig. $<\square$. Dari kondisi tersebut, dapat disimpulkan bahwa terima Ha dan tolak Ho, yang berarti bahwa: terdapat perbedaan peningkatan keterampilan membaca antara siswa yang menggunakan Digital Book dengan siswa yang menerapkan buku cetak.

Berdasarkan dua kajian di atas, keterampilan membaca awal kedua kelas adalah sama namun setelah dilakukan penelitian dengan menggunakan buku cetak untuk kelas kontrol dan Digital Book untuk kelas eksperimen dalam pembelajarannya terjadi perbedaan peningkatan keterampilan membaca. Keterampilan membaca kelas eksperimen $(76,88)$ nyata lebih besar dibandingkan dengan keterampilan membaca kelas kontrol $(63,75)$. Dengan kata lain, Digital Book yang digunakan dalam penelitian lebih efektif dalam meningkatkan keterampilan membaca siswa pada mata pelajaran agama di SMA Bidayatul Faizin.

Kesimpulan yang dapat ditarik oleh peneliti dari keterangan di atas maka hipotesis 2 yang diajukan peneliti, yaitu "Media pembelajaran digital book berbasis android efektif dalam meningkatkan keterampilan membaca siswa pada mata pelajaran Bahasa Arab di SMA Bidayatul Faizin, diterima.

\section{Pembahasan}

a. Efektivitas penggunaan media Digital Book berbasis android dalam meningkatkan motivasi belajar siswa pada pelajaran Bahasa Arab di SMA Bidayatul Faizin
Berdasarkan hasil uji perbedaan dua rata-rata, motivasi awal kedua kelas adalah sama namun setelah dilakukan penelitian dengan menggunakan buku cetak untuk kelas kontrol dan Digital Book untuk kelas eksperimen dalam pembelajarannya terjadi perbedaan peningkatan motivasi belajar. Motivasi belajar kelas eksperimen $(86,25)$ nyata lebih besar dibandingkan dengan motivasi belajar kelas kontrol (76,34). Dengan kata lain, Digital Book yang digunakan dalam penelitian lebih efektif dalam meningkatkan motivasi belajar siswa pada mata pelajaran Bahasa Arab di SMA Bidayatul Faizin.

Terjadinya peningkatan motivasi pada kelas yang menggunakan Digital Book merupakan modal bagi siswa tersebut untuk lebih maju, hal ini sesuai dengan pendapat Sardiman (2014:85) yang menyatakan motivasi dalam belajar memiliki fungsi diantaranya: mendorong manusia untuk berbuat, artinya merupakan motor penggerak dari setiap kegiatan yang akan dikerjakan; menentukan arah perbuatan, artinya dapat memberikan arah yang harus dikerjakan sesuai dengan rumusan tujuan yang telah ditetapkan; menyeleksi perbuatan, yakni memilih kegiatan yang dapat mendukung untuk mencapai tujuan serta menyisihkan kegiatan atau perbuatan-perbuatan yang tidak sesuai dengan tujuan; dan mendorong usaha dalam mencapai prestasi, seorang siswa yang memiliki motivasi yang kuat akan lebih rajin belajarnya 
sehingga hasil belajarnya pun akan lebih baik. Di dalam kegiatan belajar mengajar peranan motivasi sangat diperlukan, dengan motivasi yang baik siswa dapat mengembangkan aktivitas dan inisiatif serta dapat mengarahkan dan memelihara ketekunan dalam melakukan kegiatan belajar.

b. Efektivitas penggunaan media Digital Book berbasis android dalam meningkatkan keterampilan membaca siswa pada pelajaran Bahasa Arab di SMA Bidayatul Faizin

Berdasarkan hasil uji perbedaan dua ratarata, keterampilan membaca awal kedua kelas adalah sama namun setelah dilakukan penelitian dengan menggunakan buku cetak untuk kelas kontrol dan Digital Book untuk kelas eksperimen dalam pembelajarannya terjadi perbedaan peningkatan keterampilan membaca. Keterampilan membaca siswa kelas eksperimen $(76,88)$ nyata lebih besar dibandingkan dengan keterampilan membaca siswa kelas kontrol $(63,75)$. Dengan kata lain, Digital Book yang digunakan dalam penelitian lebih efektif dalam meningkatkan keterampilan membaca siswa pada mata pelajaran Bahasa Arab di SMA Bidayatul Faizin.

Hasil belajar (keterampilan membaca) seringkali digunakan sebagai ukuran untuk mengetahui seberapa jauh seseorang menguasai bahan yang sudah diajarkan. Keterampilan membaca dapat diukur untuk merefleksikan tujuan pengajaran. Dengan demikian keterampilan membaca dapatdiartikan sebagai perubahan perilaku siswa akibat belajar. Perubahan perilaku tersebut disebabkan karena siswa mencapai penguasaan atas sejumlah bahan yang diberikan dalam proses belajar mengajar. Pencapaian didasarkan atas tujuan pengajaran yang telah ditetapkan, hasil itu dapat berupa perubahan dalam aspek kognitif, afektif, maupun psikomotor.

Menurut Surya (1979): "prestasi belajar adalah seluruh kecakapan hasil capai (achievment) yang diperoleh melalui proses belajar yang dinyatakan dalam bentuk nilai yang diperoleh dari hasil evaluasi." Prestasi belajar yang diperoleh tidak lepas dari pengaruh dan interaksi beberapa faktor yang terlibat dalam proses belajar. Faktor-faktor tersebut diantaranya faktor eksternal seperti metode, media atau strategi pembelajaran yang digunakan oleh guru, sedangkan faktor internal adalah faktor dari dalam peserta didik itu sendiri salah satunya adalah motivasi.

Selanjutnya, multimedia dapat meningkatkan kegiatan belajar dan medianya dapat membantu membuat model mental yang lebih baik sehingga membantu pemahaman seorang pembelajar. Model pembelajaran dengan menggunakan Digital Book pada penelitian ini tidak lepas dari tujuan pembelajaran baik secara umum maupun khusus. Penentuan materi disesuaikan dengan mata pelajaran dan kebutuhan siswa.

Dari hasil penelitian di atas menunjukkan bahwa penggunaan media dalam pembelajaran yang memenuhi prinsip-prinsip penggunaan media dapat meningkatkan motivasi dan hasil belajar karena prinsipnya penggunaan media dalam pembelajaran:

1) Diarahkan untuk mempermudah siswa belajar dalam upaya 
memahami materi pembelajaran;

2) Digunakan dan diarahkan untuk mencapai tujuan pembelajaran;

3) Harus sesuai dengan materi pembelajaran;

4) Harus sesuai dengan minat, kebutuhan dan kondisi siswa;

5) Harus memperhatikan efektifitas dan efisiensi; dan,

6) Harus sesuai dengan kemampuan guru dalam pengoperasiannya.

\section{E. SIMPULAN DAN SARAN}

\section{Simpulan}

Berdasarkan hasil analisis dan penelitian serta pembahasan tentang "Penggunaan Digital Book berbasis Android untuk Meningkatkan Motivasi dan Keterampilan Membaca pada Pelajaran Bahasa Arab", maka kesimpulan yang dapat ditarik pada penelitian ini sebagai berikut:

a. Digital Book berbasis android efektif dalam meningkatkan motivasi belajar siswa pada pelajaran Bahasa Arab di kelas X (sepuluh) SMA Bidayatul Faizin tahun pelajaran 2015/2016. Secara umum, motivasi belajar siswa kelas $\mathrm{X}$ (sepuluh) meningkat setelah dilakukan kegiatan pembelajaran dengan menggunakan media digital book berbasis android;

b. Penggunaan media Digital Book berbasis android dalam kegiatan pembelajaran efektif dalam meningkatkan keterampilan membaca siswa pada pelajaran Bahasa Arab di kelas X (sepuluh) SMA Bidayatul Faizin tahun pelajaran 2015/2016;

c. Berdasarkan hasil analisis data, maka hipotesis yang diajukan diterima yaitu penggunaan digital book berbasis android efektif untuk meningkatkan motivasi dan keterampilan membaca pada pelajaran bahasa Arab di kelas X (sepuluh) SMA Bidayatul Faizin tahun pelajaran 2015/2016;

d. Berdasarkan hasil uji $t$ yang menunjukkan $\mathrm{Ha}$ diterima dan Ho, maka dapat diartikan bahwa terdapat perbedaan peningkatan motivasi belajar dan keterampilan membaca antara siswa yang menggunakan Digital Book dengan siswa yang menerapkan buku cetak.

\section{Saran}

Berdasarkan kesimpulan di atas, diajukan beberapa saran sebagai berikut:

a. Bagi para pendidik diharapkan dapat memperhatikan faktorfaktor yang mempengaruhi motivasi belajar siswa dan karakteristik pembelajaran yang efektif, sehingga pendidik dapat memahami karakteristik siswa dan kesulitan belajar siswa, dan pendidik memiliki metode dan cara yang tepat dalam melaksanakan kegiatan belajar dan pada akhirnya diperoleh hasil belajar yang sesuai dengan apa yang diharapkan;

b. Untuk sekolah diharapkan dapat melengkapi sarana dan prasarana seperti pengadaan proyektor di dalam kelas dan memperluas jaringan internet yang bisa diakses oleh seluruh komponen sekolah, karena berdasarkan hasil penelitian yang dilakukan peneliti, setiap siswa cenderung menyenangi pembelajaran dengan menggunakan berbagai media di dalam kelas, sehingga pengadaan poyektor dan jaringan internet di dalam kelas sangat pentinguntuk mempermudah proses pembelajaran;

c. Bagi siswa diharapkan selalu memotivasi diri dalam proses 
pembelajaranuntuk meningkatkan prestasi belajar;

d. Kepada pihak pemerintah lewat Dinas Pendidikan dan Kebudayaan agar tetap memberikan dukungan kepada masing-masing sekolah dalam pengembangan kurikulum pembelajaran Bahasa Arab di setiap sekolah; dan,

e. Bagi peneliti sebagai landasan untuk melakukan penelitian lebih lanjut yang didukung oleh jaringan internet, sehingga program digital book sebagai media lebih efektif digunakan dala pembelajaran Bahasa Arab.

\section{DAFTAR PUSTAKA}

Ainurrahman. (2012). Belajar dan Pembelajaran. Bandung: CV. Alfabeta.

Andi. (2012). Exploring Android On Your Own PC. Yogyakarta: Penerbit Andi. . (2014). The Best Android Apps For Chatting. Yogyakarta: Penerbit Andi

. (2014). Ragam Aplikasi Android untuk UKM. Yogyakarta: Penerbit Andi

Anonim. (2009). Documentation for Android SDK, Api 7, revision 1.

Arikunto, S. (2006). Prosedur penelitian. Jakarta: PT Rineka Cipta.

Arsyad, A. (2006). Media Pembelajaran. Jakarta: PT Raja Grafindo Persada.

Asnawir dan Usman, B. (2002). Media Pembelajaran. Jakarta: Ciputat Pers.

Asyhar, R. (2011). Kreatif Mengembangkan Media Pembelajaran. Jambi: Gaung Persada.

Buku Saku KTSP 2006 Dirjen Dikdasmen. Jakarta: Kemdiknas Darmawan, D. (2015). Teknologi Pembelajaran. Bandung: PT. Remaja Rosda Karya.
(2014). Inovasi

Pendidikan. Bandung: PT. Remaja Rosda Karya. . (2014). Pengembangan ELearning, Teori dan Desain. Bandung: PT. Remaja Rosda Karya.

(2013). Pendidikan Teknologi Informasi dan Komunikasi, Teori dan Aplikasi. Bandung: PT. Remaja Rosda Karya.

(2013). Desain dan Pemrograman Website. Bandung: PT. Remaja Rosda Karya.

Dimyati dan Mudjiono. (1994). Belajar dan Pembelajaran. Jakarta: Dirjen Dikti.

. (2002). Belajar dan

Pembelajaran. Jakarta: PT.Rineka Cipta.

Djamarah, S.B. (2005). Guru Dan Anak Didik Dalam Interaksi Edukatif. Jakarta: Rineka Cipta

Fathurrohman, P dan Sobry, M. (2011). Strategi Belajar Mengajar, Bandung: PT. Refika Aditama.

Gintings, A. (2010). Belajar Dan Pembelajaran. Bandung: Humaniora

Hamalik, O. (2006). Perencanaan Pengajaran Berdasarkan Pendekatan Sistem. Jakarta: Bumi Aksara.

Hasanah, A. (2012). Pengembangan Profesi Keguruan. Bandung: Pustaka Setia.

Hermawan S. (2011). "Mudah Membuat Aplikasi Android", penerbit Andi. 
Jones, T. dan Brown, C. (2011). Reading Engagement: A Comparison Between Ebooks And Traditional Print Books In An Elementary Classroom. International Journal of Instruction, July 2011 Vol.4, No.2.

Kementerian Pendidikan Nasional. (2010). Jurnal Teknodik (Vol.XIV No. 2 Desember 2010). Ciputat: Pustekkom.

Linawati dan Panggabean, Henri. (2004). Pengantar Multimedia. Fakutas Teknik Informatika Universitas Kristen Duta Wacana.

Munadi, Y. (2008). Media Pembelajaran: Sebuah Pendekatan. Jakarta: Gaung Persada.

Musfiqon. (2012). Media Pembelajaran. Jakarta: Prestasi Pustaka.

Norhadirijanto. (2014). Upaya Meningkatkan Keterampilan Membaca melalui Metode Suku Kata. (Skripsi). Yogyakarta: UIN Sunan Kalijaga.

Owen, V. et al. (2008). E-Books in Research Libraries: Issues of Access and Use. Canada: CARL ABRC.

Pedoman Penulisan Tesis. (2013). Pedoman Penulisan Tesis STKIP Garut.

Purwanto, N. (1986). Psikologi Pendidikan. Bandung: PT. Remaja Rosdakarya.

Ramadhani, A. (2013). Jurus Rahasia Pintar Menguasai Android. Jakata: Kir Direction.

Rosyidi, A.W. (2009). Media Pembelaaran Bahasa Arab. Malang: UIN Press

Sadiman, Arief. S., dkk. (2010). Media Pendidikan: Pengertian, Pengembangan dan Pemanfaatannya. Jakarta: PT. Raja Grafindo Persada.
Sanjaya, W. (2009). Perencanaan dan Desain Sistem Pembelajaran. Jakarta: Kencana.

(2009). Strategi Pembelajaran Berorientasi Standar Proses Pendidikan. Jakarta: Kencana.

Sardiman, A.M. (2007). Interaksi dan Motivasi Belajar Mengajar. Jakarta: PT. Raja Grafindo Persada.

(2010). Interaksi dan Motivasi Belajar Mengajar. Jakarta: Rajawali Press.

Slameto. (2003). Belajar dan FaktorFaktor Yang Mempengaruhinya. Jakarta: Rineka Cipta.

Sugiyono. (2014). Cara Mudah Menyusun: Skripsi, Tesis dan Disertasi. Bandung: CV. Albeta.

$\begin{array}{lr}\text { Penelitian } & \begin{array}{r}\text { Metode } \\ \text { (2014). }\end{array} \\ \text { Pendidikan } \\ \text { Kualitatif dan R\&D). Bandung: } \\ \text { CV. Alfabeta. }\end{array}$

Sundayana, R. (2014). Statistika Penelitian Pendidikan. Bandung: Alfabeta.

Suparno, A. S. (2001). Membangun Kompetensi Belajar. Jakarta: Dikti.

Surya, M. (2013). Psikologi Guru Konsep dan Aplikasi. Bandung: Alfabeta. . (2014). Strategi Kognitif. Garut: STKIP Press.

Suryosubroto. (2009). Proses Belajar Mengajar di Sekolah. Jakarta: PT.Rineka Cipta

Sutikono, S. (2008). Landasan Pendidikan. Bandung: Presfect. 
PEDAGOGIA : Jurnal Ilmu Pendidikan

Syah, Muhibbin. (2003). Psikologi Belajar.

Jakarta : PT Raja Grafindo Persada.

Wahyudin. (2013). Modul Statistika

Terapan. Bandung: Mandiri. 